\title{
The work of the task group of committee 2 of ICRP on age-dependent dosimetry*
}

\author{
J.W. STATHER**, A. KAUL***, H. MÉTIVIER****
}

(Manuscrit reçu le 29 mai 1995, accepté le 1er juillet 1995)

RÉSUMÉ Après l'accident de Tchernobyl et les préoccupations en découlant quant aux conséquences du déversement de radionucléides dans l'environnement, on a pris conscience du besoin d'établir les doses de rayonnement pour des groupes de population de tous les âges. En 1987, la CIPR a créé un groupe de travail relevant de son comité 2 , chargé de la dosimétrie selon les âges. Ce groupe est responsable du calcul des coefficients de dose - au niveau international - pour les membres du public. Son travail comporte le calcul des doses reçues par les individus de divers âges, à la suite de la prise de radionucléides par inhalation et par ingestion ; il comporte aussi le calcul des doses à l'embryon et au fœtus, lorsque la mère a absorbé des radionucléides. Cet article passe en revue le programme de travail du groupe.

ABSTRACT With the accident at Chernobyl and developing concern in regard to the consequences of discharging radionuclides into the environment has come increasing awareness of the need to assess radiation doses to all age groups in the population. In 1987, ICRP set up a Task Group of Committee 2 on Age-dependent Dosimetry with the responsibility for calculating internationally agreed dose coefficients for members of the public. This covered the calculation of doses to individuals of different ages for intakes of radionuclides by inhalation and ingestion, as well as doses to the embryo and fetus from intakes of radionuclides by the mother. This paper reviews the programme of work.

\section{Introduction}

In 1987, the International Commission on Radiological Protection (ICRP) set up a task group of committee 2 charged with the responsibility for calculating age-dependent dose coefficients (doses per unit intake) for members of the public resulting from the release of radionuclides into the environment. This group, now the task group on internal dosimetry (INDOS), in conjunction with the ICRP Task Group on Dose Calculations, has issued publications 56 (ICRP,

\footnotetext{
* Ce texte fait partie d'une série d'articles de synthèse consacrés à la dosimétrie et qui sera publiée durant l'année 1996.

** National Radiological Protection Board, Chilton, Didcot, Oxon, U.K.

*** Bundesamt für Strahlenschutz, Oberschleißheim, Germany.

**** Institut de Protection et de Sûreté Nucléaire, Fontenay-aux-Roses, France.
} 
1989), 67 (ICRP, 1993) and 69 (ICRP, 1995) giving ingestion dose coefficients for reference age groups in the population for intakes of the most radiologically significant radioisotopes of selected elements. Preliminary inhalation dose coefficients, using the publication 30 (ICRP, 1979) lung model were also given in publication 56 . With the issue of the new respiratory tract model in publication 66 (ICRP, 1994) a further report (publication 71) will be issued which will give inhalation dose coefficients using this new model for all the radioisotopes given in publications 56, 67 and 69 and for radioisotopes of calcium and curium. A compilation of dose coefficients in these reports is also being prepared.

Additionally, the task group is preparing reports on doses to the embryo and fetus following acute or chronic intakes of radionuclides by the mother either before or during gestation and on the reliability of dose coefficients.

\section{Infants, children and adult members of the public}

A series of ICRP publications have either been issued (publications 56, 67 and 69) or are in preparation (publication 71) on age-dependent doses to members of the public from intakes of radionuclides. They have the following objectives:

- to identify the most radiologically significant radioisotopes of elements that might be released to the environment due to various human activities;

- to select age-dependent biokinetic data for these elements;

- to assess dose coefficients (doses per unit intake) for intakes by ingestion and inhalation of the radioisotopes considered for representative members of the public of various ages.

Publication 56 (ICRP, 1989) gave dose coefficients for various age groups in the population (3-month-old infants, 1-, 5-, 10-, and 15 year-old children, and adults) for ingestion and inhalation of the most radiologically significant radioisotopes of 12 elements using the tissue weighting factors, $w_{\mathrm{T}}$ in ICRP publication 26. Publication 67 (ICRP, 1993) gave ingestion dose coefficients for important isotopes of a further 12 elements using the new $w_{\mathrm{T}}$ values recommended by ICRP in publication 60 . Revised ingestion dose coefficients for the radionuclides in publication 56 were also given in publication 67 using the new $w_{\mathrm{T}}$ values. Models for the alkaline earths and actinides were also updated. A third report, publication 69 gave ingestion dose coefficients for isotopes of an additional five elements. A fourth report (ICRP publication 71) on age-dependent inhalation dose coefficients using the new model for the respiratory tract (ICRP, 1994) is also planned. A final report in this series, giving a compilation of the dose coefficients in the previous reports is also planned. The approach adopted by the task group for the development of these reports, which are summarised in Table $I$, is given below. 
TABLE I

Summary of reports on age-dependent dose coefficients for members of the public from intakes of radionuclides

Résumé des valeurs publiées des coefficients de dose selon l'âge, pour les personnes du public, à la suite de la prise de radionucléides

\begin{tabular}{|c|c|c|c|c|c|}
\hline (3) & ard & 10 & $a n t$ & $\mathrm{art}$ & $\operatorname{art} 5$ \\
\hline ICRP Publicationg) & 56 & 67 & 69 & 71 & $72^{f)}$ \\
\hline Ingestion Dose Coefficients & + & + & + & - & + \\
\hline GI Tract Modelg) & 30 & 30 & 30 & 30 & 30 \\
\hline Inhalation Dose Coefficients & + & - & - & + & + \\
\hline Respiratory Tract Modelg) & 30 & na & na & 66 & 66 \\
\hline Tissue Weighting Factorsg) & 30 & 60 & 60 & 60 & 60 \\
\hline
\end{tabular}

For radioisotopes of :

a) H, C, Sr, Zr, Nb, Ru, I, Cs, Ce, Pu, Am and Np; b) S, Co, Ni, Zn, Mo, Tc, Ag, Te, Ba, Pb, Po and $\mathrm{Ra}$; c) $\mathrm{Fe}, \mathrm{Sb}, \mathrm{Se}$, Th, U ; d) Elements in parts 1,2 and 3 plus $\mathrm{Ca}$ and $\mathrm{Cm}$; e) Compilation of dose coefficients in parts $1-4$; f) Anticipated publication no; g) Publication no.; +/- dose coefficients given/not given in report; na not applicable.

\section{Ingestion}

The dosimetric model for the gastrointestinal (GI) tract used in publications 56, 67 and 69 is that given in ICRP publication 30 (ICRP, 1979). Parameters for the adult are taken to apply to all ages because specific age-dependent information on the mean residence time for the four compartments of the GI tract (stomach, small intestine, upper large intestine and lower large intestine) was not available. It is recognised that the transit time of material through the GI tract varies with age, with retention in children being significantly less than in adults. Except for short-lived radionuclides, this may lead to some overestimation of the dose to the different regions of the gastrointestinal tract in children.

The values of gut absorption factor $\left(f_{1}\right)$ recommended in publication 30 apply specifically to intakes of chemical forms of elements expected to be encountered in the workplace and are not necessarily appropriate for radionuclides associated with food and drinking water. The task group therefore reviewed the most appropriate $f_{1}$ values to adopt for such intakes by members of the public. In this they considered on the work of an expert group of the Nuclear Energy Agency (NEA) of the Organisation for Economic Cooperation and Development (OECD) that had reviewed information on the absorption of selected radionuclides present in foods (NEA, 1988). Additionally, they reviewed more recently published information. There is also evidence that the 
absorption of radionuclides tends to be greater in the newborn, although animal studies suggest the enhancement of gut transfer progressively decreases with increasing age, in most cases reaching adult values by about the time of weaning. The $f_{1}$ values for adults can therefore be taken to apply to children of 1 year of age or older. For younger children the NEA expert group had recommended a general approach for estimating $f_{1}$ values for infants in the first year of life when no human or animal data are available. It was based on the experimental data available for a number of elements. For $f_{1}$ values between 0.01 and 0.5 in the adult, an increase by a factor of two is assumed for the first year of life, but for elements with a fractional absorption in the adult of 0.001 or less, a value 10 times the adult value for the adult is assumed. This approach was adopted by the task group with the higher $f_{1}$ values used for calculating dose coefficients for the three-month-old infant. For $f_{1}$ values of 0.5 or greater in the adult complete absorption was assumed in the 3-month-old infant. There are no elements in publications 56, 67 and 69 with $f_{1}$ values between 0.01 and 0.001 .

\section{Inhalation}

Although a task group of committee 2 was preparing a report on a revised age-dependent dosimetric model for the respiratory tract this was not available for publication 56. The lung model recommended for adults in publication 30 (ICRP, 1979) was therefore used for calculating preliminary inhalation dose coefficients for all ages. This model does not make any allowance for agedependent changes in deposition of inhaled material. For the dose coefficients given in publication 56 allowance is only made for age-related changes in lung mass and biokinetic data for radionuclides transferred to body fluids. No inhalation dose coefficients are given in publications 67 and 69.

With the issue of the new respiratory tract model in publication 66 (1994), a further report (ICRP publication 71) will give age-dependent inhalation dose coefficients for the public for radioisotopes of all the 29 elements given in publications 56, 67 and 69. Some additional short-lived radionuclides will also be included. Dose coefficients for radioisotopes of curium will be calculated using the same biokinetic model as that developed for americium and for radioisotopes of calcium using the generic model for the alkaline earths. The new respiratory tract model gives three default lung absorption types which are similar to the clearance classes given in the publication 30 model. Dose coefficients will be given for all three lung absorption types recommended in the model (termed Fast, Moderate and Slow). The task group has summarised human studies and experimental data on the behaviour of inhaled radionuclides to permit a choice to be made of the appropriate lung absorption type(s) for chemical forms likely to be released into the environment; a default type (commonly type $\mathrm{M}$ ) will be recommended when no information is available. Appropriate $f_{1}$ values for material cleared from the lung via the GI tract also needed to be selected. The biokinetic models for material translocated to the 
blood are those given in publications 56, 67 and 69. Additionally, the report will contain a summary of the new respiratory tract model and the habit data (e.g., respiratory parameters) adopted for the various age groups. Calculations will be based on a default activity median aerodynamic diameter (AMAD) of $1 \mu \mathrm{m}$. This report will be published in 1996 .

\section{Translocation of elements from body fluids to organs and tissues}

After translocation from the GI tract or lungs into body fluids, i.e., the transfer compartment, an element is assumed to be cleared to organs, tissues or excreta according to the model used in publication 30. However, since the 1990 recommendations of ICRP include weighting factors for organs of the excretory system, a generic excretion model is applied when the element specific model does not include excretion. This is discussed below. Unless specified otherwise in the biokinetic data tables, a half-time in the body fluids of 0.25 days is assumed and taken to be independent of age and gender.

\section{Age-specific biokinetics of elements}

Distribution and retention of radionuclides in body tissues after entry into body fluids is element-specific and may be age-dependent. The task group has reviewed the available biokinetic information for the elements considered in publications 56, 67 and 69. In the development of biokinetic models, human data were used when available. If no relevant data could be found appropriate information from animal experiments was used.

For a number of radionuclides sufficient data were available to be able to make recommendations on age-specific biokinetic parameters (e.g., for tritium, carbon, iodine, strontium, caesium and plutonium), although the extent of the information available is very variable. For other elements (e.g. zirconium and ruthenium), insufficient age-specific data are available and adult biokinetic parameters were adopted for all ages. When retention parameters for the adult are used for infants and children, this is usually expected to lead to an overestimation of the dose coefficients.

A specific problem had to be addressed by the task group in calculating doses to the red bone marrow and to cells on bone surfaces from skeletal deposits of radionuclides as the ICRP publication 30 model for bone volume-and bone surface-seeking radionuclides is not suitable for determining age-specific dose coefficients. Thus, in publication 30 the actinide plutonium is assumed to be a bone surface-seeking radionuclide in adults and to be retained on bone surfaces throughout life. This is a conservative assumption. In practice, evidence from animal studies and human data indicate that a fraction of plutonium becomes buried as a result of bone growth and turnover, whilst a further fraction is resorbed. Some of this fraction may be redeposited in the skeleton or be taken up by the liver, bone marrow, or be excreted. Other actinides 
behave similarly. In contrast, long lived isotopes of radium and of other alkaline earths are taken to be bone volume seekers in publication 30 and to rapidly distribute throughout bone mineral. They are progressively lost from the body as a result of bone growth and remodelling. The processes of bone turnover are more important in infants and young children than in adults and will result in faster burial and recycling of radionuclides deposited in the skeleton. To allow for the known features of the behaviour of radionuclides in the skeleton and to permit the development of age-dependent parameters, generic models have been adopted in publications 67, 69 and 71 for bone-seeking radionuclides which allow for the known physiology of the bone as it varies with age as well as information on the behaviour of specific radionuclides. Generic models have been developed for plutonium and other actinides (Am, $\mathrm{Np}, \mathrm{Th}$ ) and for the alkaline earths ( $\mathrm{Ca}, \mathrm{Sr}, \mathrm{Ba}$ and $\mathrm{Ra}$ ). The alkaline earth model has also been applied with some modifications to lead and to uranium. For other elements retained in the skeleton for long periods, but for which no retention data are available (e.g., zirconium), age-dependent biological halftimes have been adopted based on the turnover rate of cortical bone.

A number of radionuclides decay to isotopes of other elements which are themselves radioactive. The usual assumption in publication 30 was that these radioactive decay products followed the biokinetics of their parent; there were a few exceptions for decay products which were isotopes of iodine or noble gases. In publications 56, 67, 69 and 71 separate systemic biokinetics have also been applied to the parent and its decay products for intakes of lead, radium, tellurium, thorium and uranium. For other elements, the treatment of decay products follows that in publication 30 . It is likely that further recommendations regarding the behaviour of decay products in the body will be made in due course in the revision of publication 30 .

\section{Excretion pathways}

In the 1990 recommendations of ICRP (ICRP, 1991), the urinary bladder and the colon are given explicit $w_{\mathrm{T}}$ values. Consequently, the equivalent doses from systemic activity being excreted in urine or faeces have been considered. Publication 67 adopted an age-dependent biokinetic model for the urinary bladder based on the models of Snyder and Ford (1976) and Smith et al. (1982). In this model the bladder is taken to be of fixed size with a volume for each age representing the average content of the bladder during the time period between voids. The rate at which radionuclides enter the bladder depends upon the elimination rate from body tissues. The number of voids per day is taken to be 20 and 16 respectively for the 3-month-old and 1-year-old. For all other ages, the number of voids per day is taken to be 6 (equivalent to a half-time of about $1.4 \mathrm{~h}$ ). The loss of systemic activity from the body by urinary and faecal excretion is given with the data on biokinetic models in publications 67, 69 and 71. The dose to the colon, for which a $w_{\mathrm{T}}$ is specified in publication 60 is calculated as the mass weighted average equivalent dose to the upper and lower large intestine. 


\section{Dose coefficients}

The dose coefficients given in the report $\left(\mathrm{Sv} \mathrm{Bq}^{-1}\right)$ are generally calculated to age 70 years and are based on intakes of radionuclide at six different ages; 3-month-old infants, 1-, 5-, 10-, and 15-year-old children, and 20-year-old adults. These age groups are chosen to provide representative values for assessing doses from intakes of radionuclides by the general population. Exceptions are made for the alkaline earth elements, lead and the actinides. For these elements, the transfer rates for the adult apply to ages $\geq 25$ years, and dose coefficients for the adult are based on equivalent dose rates received over a 50-year period following acute intakes at age 25 years. The task group considered that these age-specific dose coefficients may also be reasonably applied to the age ranges of $0-12$ months, $>1-2$ years, $>2-7$ years, $>7-12$ years, $>12-17$ years and for the adult of more than 17 years of age respectively. For the assessment of dose coefficients after intakes of radionuclides at the above ages, a continuous change of $f_{1}$ values, distribution factors and biological half-times was assumed using linear interpolation of the data according to age.

The dose coefficients calculated in publications 56, 67, 69 and 71 are for acute intakes. For intakes over an extended period, doses per unit intake could be somewhat lower than those calculated here where growth is significant during the period of intake. However, since the age ranges were selected to account for significant changes in growth and biokinetics during life, these coefficients can also be applied to other patterns of intake for protection purposes by determining the committed dose for each year's intake and summing for intakes over all years.

\section{Presentation of the biokinetic and dosimetric data}

A standardised approach has been adopted for presenting the biokinetic data of the elements and the dose coefficients of the radioisotopes of these elements in publications 56, 67 and 69. The format is:

a) uptake to blood from the GI tract for adults, infants and children $\left(f_{1}\right.$ values) ;

b) distribution and retention for adults, infants and children;

c) classification of the radioisotopes for bone dosimetry (if relevant);

d) behaviour of decay products;

e) biokinetic data for the element summarised in a standard tabular form;

f) urinary to faecal excretion rates;

g) dose coefficients $\left(\mathrm{Sv} \mathrm{Bq}{ }^{-1}\right)$, to age 70 years for intakes of radioisotopes of the elements considered in standard tabular format for 21 target organs and remainder tissues as well as the effective dose for the 6 representative age groups considered.

Typical biokinetic data tables are shown in Tables IIa-d for tritiated water, ${ }^{14} \mathrm{C}$, iodine and caesium. Table IIIa summarises dose coefficients for ingestion 
of tritiated water, ${ }^{14} \mathrm{C},{ }^{90} \mathrm{Sr},{ }^{131} \mathrm{I},{ }^{137} \mathrm{Cs}$, and ${ }^{239} \mathrm{Pu}$ for 3 -month-old infants, 1 and 10-year-old children and adults from publication 67. In general, dose coefficients are higher in the younger age groups than in adults because of the smaller body mass, although the difference between the various ages is very variable and is also influenced by age-dependent differences in biokinetic parameters. For ${ }^{137} \mathrm{Cs}\left(f_{1}=1\right.$ for all ages) the rate of loss of caesium from the body is faster in children than in adults and as a consequence there is little overall difference in the dose coefficients for the different ages. Similar considerations apply to ${ }^{3} \mathrm{H}_{2} \mathrm{O}$ and ${ }^{14} \mathrm{C}$. For ${ }^{131} \mathrm{I}\left(f_{1}=1\right.$ for all ages) the half-time of retention in children is less than in adults but the fractional uptake by the thyroid gland (0.3) appears to be independent of age. The effective half-time in the gland is, however, largely determined by the physical half-life of the isotope ( 8 days) and as a consequence the 8-fold difference in the dose coefficients for the different ages mainly reflects the differences in thyroid mass. For ${ }^{239} \mathrm{Pu}$ there is a 17-fold difference between the 3-month-old infant and the adult, which mainly reflects the differences in $f_{1}$ values for the two ages $\left(f_{1}=510^{-3}\right.$ and $510^{-4}$ respectively). For ${ }^{90} \mathrm{Sr}$ the $f_{1}$ for the 3 month-old is twice that for the adult and this, together with differences in body mass and skeletal retention, accounts for the 8-fold difference in the dose coefficient.

\section{TABLE II}

Biokinetic data tables from ICRP publication 56 (1989)

a) Biokinetic data for tritiated water; b) Biokinetic data for ${ }^{14} \mathrm{C}$; c) Biokinetic data for iodine; d) Biokinetic data for caesium Table de données biocinétiques, d'après la publication CIPR 56 (1989)

a) Données biocinétiques pour l'eau tritiée; b) Données biocinétiques pour 14C; c) Données biocinétiques pour l'iode; d) Données biocinétiques pour le césium

a)

\begin{tabular}{|c|c|c|c|c|}
\hline Age & D & 3 & $\begin{array}{l}\text { Biol } \\
\text { Comp. A }\end{array}$ & Comp \\
\hline 3 months & 97 & 3 & 3.0 & 8.0 \\
\hline 1 year & 97 & 3 & 3.5 & 15 \\
\hline 5 years & 97 & 3 & 4.6 & 19 \\
\hline 10 years & 97 & 3 & 5.7 & 26 \\
\hline 15 years & 97 & 3 & 7.9 & 32 \\
\hline Adult & 97 & 3 & $10.0^{\mathrm{a})}$ & $\left.40.0^{a}\right)$ \\
\hline
\end{tabular}

a) Rounded values according to ICRP publication 30 (ICRP, 1979) ; b) The concentration in urine is assumed to be the same as in total body water. 
b)

\begin{tabular}{|lcc|}
\hline \multicolumn{1}{|c|}{ Age } & $\begin{array}{c}\text { Distribution (\%) } \\
\text { Total body }\end{array}$ & Biological half-time (d) \\
\hline 3 months & 100 & 8 \\
1 year & 100 & 15 \\
5 years & 100 & 19 \\
10 years & 100 & 26 \\
15 years & 100 & 32 \\
Adult & $100^{\mathrm{a})}$ & $40^{\mathrm{a})}$ \\
\hline
\end{tabular}

a) Values from ICRP publication 30 (ICRP, 1979) ; b) Excretion will not result in a significant additional dose to the bladder wall and colon (lower and upper large intestine), both of which are assumed to receive the same dose as other tissues.

c)

\begin{tabular}{|c|c|c|c|c|c|c|c|}
\hline Age & $f_{1}$ & $\begin{array}{c}\text { Uptake by } \\
\text { thyroid } \\
\%\end{array}$ & $\begin{array}{c}\text { Faecal } \\
\text { excretion } \\
\%\end{array}$ & $\begin{array}{c}\text { Biol } \\
\text { Blood } \\
T_{\mathrm{a}}\end{array}$ & $\begin{array}{l}\text { ical half- } \\
\text { Thyroid } \\
T_{b}\end{array}$ & $\begin{array}{l}\text { ne (d) } \\
\text { Rest of } \\
\text { body } T_{\text {c }}\end{array}$ & $\begin{array}{l}\text { "Apparent } \\
\text { half-time" (d) } \\
\text { Thyroida) }\end{array}$ \\
\hline 3 months & 1 & 30 & 20 & 0.25 & 11.2 & 1.12 & 15 \\
\hline 1 year & 1 & 30 & 20 & 0.25 & 15 & 1.5 & 20 \\
\hline 5 years & 1 & 30 & 20 & 0.25 & 23 & 2.3 & 30 \\
\hline 10 years & 1 & 30 & 20 & 0.25 & 58 & 5.8 & 70 \\
\hline 15 years & 1 & 30 & 20 & 0.25 & 67 & 6.7 & 80 \\
\hline Adult & $1^{b)}$ & $30^{b)}$ & 20 & $\left.0.25^{b}\right)$ & $\left.80^{b}\right)$ & $12^{b)}$ & 91 \\
\hline
\end{tabular}

a) Between 2 and 16 days after intake to the thyroid; b) Value from ICRP publication 30 (ICRP, 1979).

d)

\begin{tabular}{|c|c|c|c|c|c|}
\hline $\mathbf{A g e}$ & $\begin{array}{l}1,89 \\
f_{1}, \\
\end{array}$ & $\begin{array}{r}\mathrm{Di} \\
\mathrm{A} \\
\mathrm{P}\end{array}$ & $\begin{array}{r}\text { fon }(\%) \\
\text { body } \\
\text { B } \\
\end{array}$ & $\begin{array}{r}\text { Biol } \\
\mathbf{A} \\
\end{array}$ & $\begin{array}{l}\mathbf{f} \text {-time } \\
\mathbf{y} \\
\mathbf{B} \\
\end{array}$ \\
\hline 3 months & 1 & - & 100 & - & 16 \\
\hline 1 year & 1 & - & 100 & - & 13 \\
\hline 5 years & 1 & 45 & 55 & 9.1 & 30 \\
\hline 10 years & 1 & 30 & 70 & 5.8 & 50 \\
\hline 15 years & 1 & 13 & 87 & 2.2 & 93 \\
\hline Adult & 1a) & $10^{a)}$ & $90^{\text {a) }}$ & $2^{\text {a) }}$ & $110^{a)}$ \\
\hline
\end{tabular}

a) Values from ICRP publication 30 (ICRP, 1979); appropriate for males; conservative if applied for calculating dose coefficients for females; b) A urinary to faecal excretion ratio of $4: 1$ is assumed for caesium that has entered the transfer compartment. 
TABLE III

a) Ingestion dose coefficients to age 70 years. ICRP publication 67 (1993) ;

b) Inhalation dose coefficients to age 70 years. ICRP publication 71 (1996)

a) Coefficients de dose par ingestion, jusqu'à l'âge de 70 ans.

CIPR, publication 67 (1993) ; b) Coefficients de dose par inhalation jusqu'à l'âge de 70 ans. CIPR, publication 71 (1996)

a)

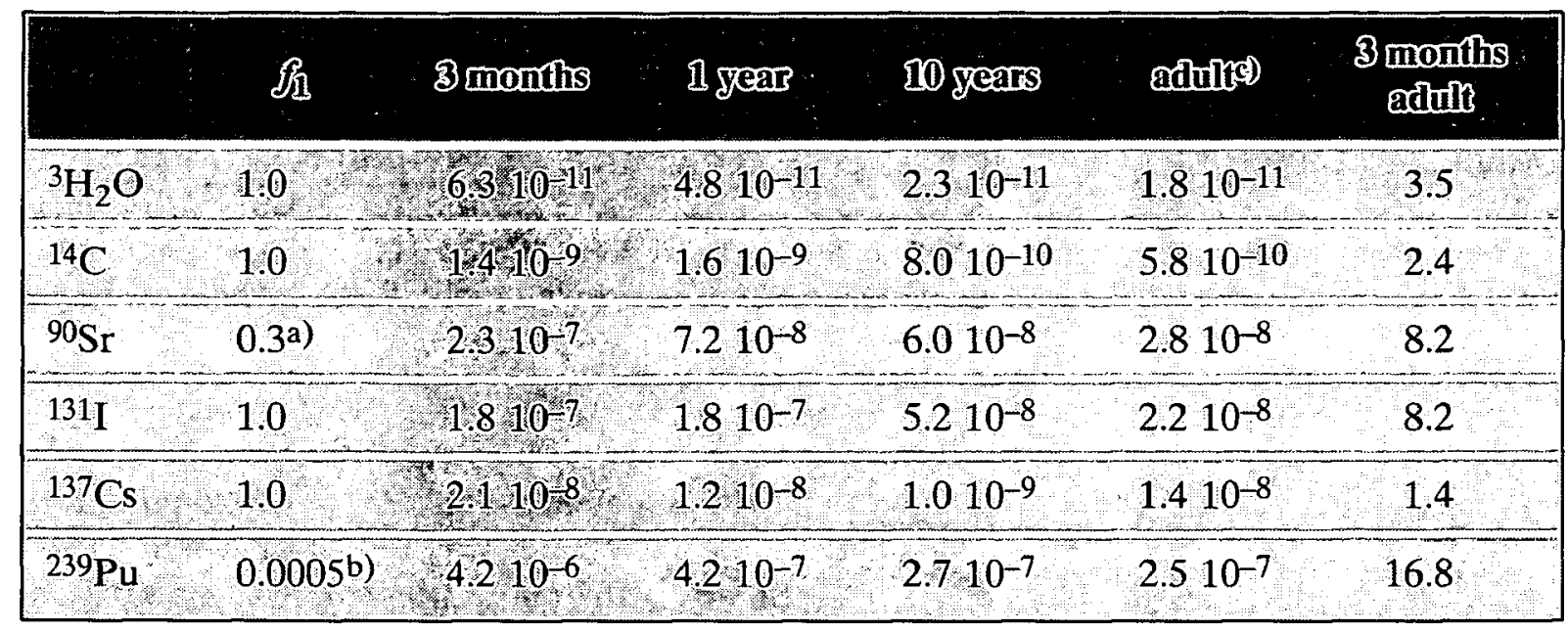

a) 0.6 for 3 month-old ; b) 0.005 for 3 month-old ; c) 20 years.

b)

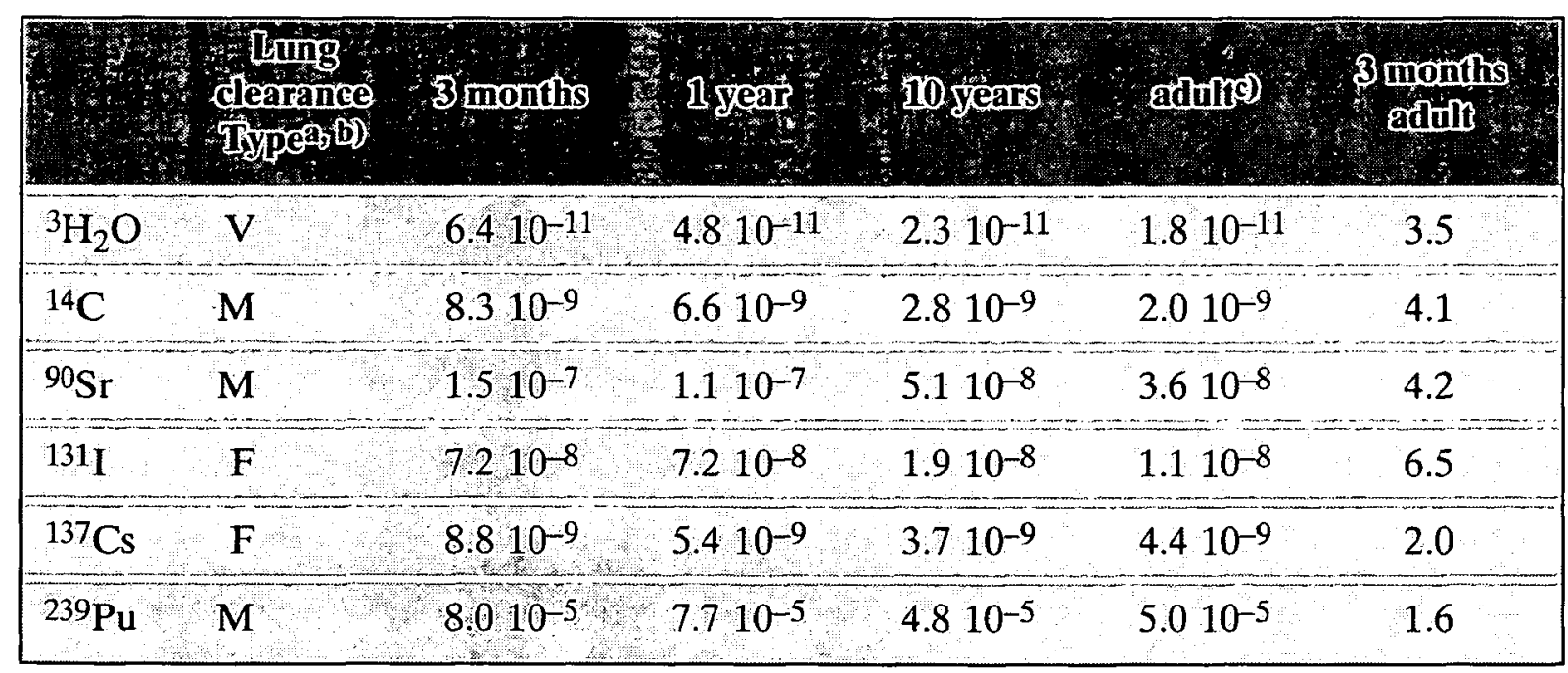

a) Activity median aerodynamic diameter $=1 \mu \mathrm{m}$ for types $\mathrm{M}$ and $\mathrm{F} ; \mathrm{b}$ ) Default lung type.

In publication 71 , giving inhalation dose coefficients for radionuclides of all the elements covered in publications 56, 67 and 69, emphasis is placed on reviewing data on the clearance of radionuclides from the respiratory system following inhalation in various chemical forms. Information is also presented on the behaviour of inhaled gases and vapours, together with appropriate dose coefficients. Table IIIb gives representative inhalation dose coefficients for the radionuclides given in Table IIIa. 


\section{Compilation of data on dose coefficients}

The committed equivalent doses and committed effective doses given in publications 67,69 and 71 are to be compiled in a final report in this series giving both ingestion and inhalation coefficients for all the radionuclides covered in these reports. In addition, this report will contain committed effective doses, for intakes by both ingestion and inhalation for radionuclides of all the elements covered in publication 30 that were not covered in the earlier publications. For these additional elements, the models used for the biokinetics of systemic activity are those given in publication 30 and are not age-dependent. Age-dependent parameters have been used only for body mass and excretion. The dose coefficients will therefore need to be used with care for younger ages. The compilation of dose coefficients will be issued as Publication 72.

\section{Embryo and fetus}

The task group is preparing a report giving dose coefficients for the embryo and fetus following intakes of radionuclides by the mother.

Whilst dosimetric models for infants and children can generally be based on those developed for adults, with appropriate modifications to biokinetic parameters, in the case of the embryo and fetus fundamentally new models need to be developed. Such models are important for assessing doses to the fetus for women who may be exposed occupationally or following the release of radionuclides into the environment. They are also needed when radiolabelled drugs are administered for clinical reasons during pregnancy. In the 1990 recommendations of ICRP (ICRP, 1991) particular emphasis is placed on measures to control exposures in utero for women who are occupationally exposed. This arises because of the recognition of the greater sensitivity of developing tissues to ionising radiation and the need to treat the fetus broadly as a member of the public.

\section{Stages of development}

When calculating doses from incorporated radionuclides it is essential to separate the different stages in development of the conceptus. For the purposes of dosimetry a number of stages may be recognised:

Pre-implantation: In most mammalian species, the ovum passes from the oviduct into the uterine lumen a few days after fertilization and implants in the mucosa through a complex series of processes about 2 to 3 days later, i.e. at about 6 to 7 days after fertilization. The timing of this initial period is very similar in most mammalian species (Tab. IV).

The embryo: After embedding in the epithelial lining of the uterus the implanted embryo becomes closely surrounded by maternal tissue, the progressive erosion of this tissue constituting a source of nourishment. This period of 
organ formation may be considered to last up to about the end of the second month, at which time the developing embryo still weighs less than $10 \mathrm{~g}$ (Moore, 1977). Because of the close apposition between the embryo and uterus wall it has been commonly assumed, in the absence of more specific information, that the dose to the embryo, up to the end of the second month of gestation, can be approximated by the dose to the uterus. While this may be a reasonable approximation for many $\beta / \gamma$ emitters it is not necessarily the case for alpha emitters which have a short path length (a few tens of $\mu \mathrm{m}$ ) in tissue.

The fetus: From the end of organogenesis (taken to be 60 days post conception in man, Tab. IV) progressive histogenesis and growth are the characteristic processes that take place during the fetal period. There are, however, significant differences between species during this latter stage of pregnancy. The human fetus, as with most other mammalian species, is contained in the amniotic fluid where it is surrounded by fetal membranes and nourished via the placenta through the umbilical cord. The weight of the newborn child is about $3.5 \mathrm{~kg}$ and thus the mass of the conceptus has increased about five-hundred fold from the end of the embryonic period and by more than a factor of $10^{7}$ since conception.

The newborn child: The radiation dose to the newborn child arising from activity present at birth also needs to be estimated. The calculated body content may be used to calculate the committed dose to age 70 years using the biokinetic models for infants and children given in publications 56, 67, 69 and 71 .

\section{TABLE IV}

Approximate time (d) of the beginning and end of the major developmental periods in some mammalian species

Valeur approchée du temps (j) de début et de fin des périodes majeures de développement dans quelques espèces de mammifères

\begin{tabular}{|c|c|c|c|}
\hline 1. Species & uplan & $\begin{array}{l}\text { Major } \\
\text { anoger } \\
\text { anoger }\end{array}$ & $\begin{array}{l}\text { troncep } \\
\text { conlperio } \\
\text { tal per }\end{array}$ \\
\hline Hamster & $0-5$ & $6-12$ & $13-16.5$ \\
\hline Mouse & $0-5$ & $6-13$ & $14-19.5$ \\
\hline Rat & $0-7$ & $8-15$ & $16-21.5$ \\
\hline Rabbit & $0-5$ & $6-15$ & $16-31.5$ \\
\hline Guinea-pig & $0-8$ & $9-25$ & $26-63$ \\
\hline Dog & $0-17$ & $18-30$ & $31-63$ \\
\hline Man & $0-8$ & $9-60$ & $60-270$ \\
\hline
\end{tabular}

UNSCEAR (1977). 


\section{Dosimetric and biokinetic models}

Transfer of radionuclides to the fetus: Radioactive materials have to cross a number of membrane barriers to reach the tissues of the embryo and fetus from the maternal circulation. The processes involved in this transfer include simple diffusion, facilitated transport, active transport, movement through pores and channels, and pinocytosis (Stieve, 1984, 1987). Radionuclides which are isotopes of stable elements that are required by the developing embryo/fetus will follow the normal pathways for that element (e.g., $\mathrm{Na}, \mathrm{K}$, $\mathrm{Ca}$ ). Isotopes of elements that have similar chemical properties to essential elements are likely to follow comparable pathways, although the rates of transfer may differ (e.g., Cs behaves similarly to $\mathrm{K}$, Sr behaves similarly to $\mathrm{Ca}$ ). For other radionuclides the rates of transfer to the embryo and fetus will depend upon their chemical affinity for different transport systems in the body and, as a result, the extent of uptake is unpredictable.

Most available human data on placental transfer of radionuclides are available from studies with labelled metabolites or pharmaceuticals although some data are available for radionuclides in weapons fallout (isotopes of $\mathrm{Cs}, \mathrm{Sr}, \mathrm{I}$ ). Analyses of autopsy samples have given some information on both naturally occurring and artificially produced radionuclides and some comparative information has been obtained through in vitro perfusion studies using human placentae. The rather limited amount of human data makes it essential to use the results of animal studies in the development of dosimetric models for the human, although even here information is frequently very limited. The pattern of results obtained experimentally for most radionuclides is similar, although overall transfer to the newborn fetus is very variable. In general, concentrations of radionuclides in the fetus at birth are highest following intakes towards the end of pregnancy although the concentrations are less than in maternal tissues. For some bone-seeking radionuclides (e.g., Sr) administered at the end of gestation, however, the concentration may be higher in the fetus than the mother, reflecting the demand of the rapidly developing skeleton for calcium. The concentration of radionuclides in the fetal thyroid is about double that in the mother from about the tenth week of gestation.

Development of dosimetric models: In the extrapolation of animal data to man, care is needed; particular problems. in the development of dosimetric models include: the varying progress of organ development in different species ; the presence of several types of placentae in different species, all of which provide a selective but potentially different barrier between maternal and fetal blood; the rapidity of growth; the complex pattern of growth and differentiation with the potential for quite different distributions of radionuclides in the embryo and fetus from that of the mother; and uncertainty about the location of sensitive cells at various stages of development. Doses to the fetus from maternal deposits of radionuclides also need to be assessed, both from direct irradiation and from the transfer of radionuclides from maternal tissues. A general approach is envisaged for the development of dosimetric models which will be modified where specific data are available. 
For the embryo (to 60 days after conception), the dose is based on that to the uterus. For the fetus, when the radiation dose is determined mainly by the activity translocated to it across the placenta, the assessment of fetal organ/tissue dose, can, in principle, be derived from the maternal organ/tissue dose, by correcting for activity concentrations, half-lives and absorbed fractions. In practice, however, published results may only give data on relative concentration ratios in the fetal and maternal tissues $\left(C_{\mathrm{F}} / C_{\mathrm{M}}\right)$ and details of the distribution of radionuclide in fetal tissues are often not given. The general approach that has been adopted by the task group for calculating the dose to the developing fetus, where specific information is not available, is to use as a basis for dose calculations experimentally determined $C_{\mathrm{F}} / C_{\mathrm{M}}$ ratios obtained shortly after administration. This is likely to be conservative as rapid growth of the fetus is expected to reduce the concentration of radionuclides in fetal tissue, although this dilution effect may be to some extent offset by transfer of radionuclides to the fetus from deposits in the maternal tissues. A number of radionuclides would be expected to equilibrate rapidly between maternal and fetal tissues. These include isotopes of the alkali metals, which are predominantly ionic in body fluids and have a rapid turnover in tissues, as well as many tritium and ${ }^{14} \mathrm{C}$ labelled compounds.

For the majority of radionuclides, activity deposited in maternal tissues will also contribute to the dose to the fetus. In the absence of complete dosimetric models for the pregnant woman this dose has been provisionally taken to be the same as the dose to the uterus. A dosimetric model for the pregnant female is being developed and will be used in the calculations when it is available.

As indicated above, in many animal studies the distribution of radionuclide in fetal tissues is not reported and the assumption has to be made for calculating doses that the distribution in the fetus is the same as that in the mother. Recent autoradiographic studies, however, have shown that following administration to the mother at various times during gestation there can be a significant uptake of some radionuclides in the yolk sac membranes (e.g., ${ }^{95} \mathrm{Nb}$, ${ }^{106} \mathrm{Ru},{ }^{210} \mathrm{Po}$ and ${ }^{239} \mathrm{Pu}$ ). This may be of importance as haemopoietic development involves the migration of stem cells and it appears likely that the primitive stem cell population may arise in the yolk sac, or even at the earlier egg cylinder stage. These stem cells may subsequently migrate to the liver once the extraembryonic and embryonic circulations become connected. Ultimately haemopoietic stem cells migrate to the bone marrow. It has been proposed that for calculating doses to the haemopoietic stem cells in the developing fetus, for radionuclides showing concentrations in yolk sac membranes, the appropriate dose should reflect this migration, taking into account appropriate periods of gestation in the human.

\section{Dose coefficients for the embryo and fetus}

For the calculation of dose coefficients a range of intake patterns by the mother have been adopted which should allow doses to the embryo and fetus 
to be determined for any pattern of exposure of the mother. For acute exposures, intakes of radionuclides are taken to occur at the start of weeks $1,5,10$, 15,25 and 35 of the pregnancy and at 6 months and $21 / 2$ years before conception. For chronic exposures, intakes are taken to occur during the year of pregnancy starting from the time of conception, for 1 year before conception or for 5 years before conception. It is proposed that in the final report equivalent doses to the date of birth will be given for the embryo and fetus for all tissues with a specific accumulation of radionuclide as well as the average dose to remainder tissues (calculated as the mass weighted average). The effective dose will also be given using the $w_{\mathrm{T}}$ values recommended by ICRP in Publication 60 . Whilst these values are not strictly appropriate for exposures in utero, they have been used as no alternative weighting factors are presently available. The effective dose provides a useful quantity for assessing the consequences of different patterns of intake of radionuclides and for comparison with maternal doses. Effective doses (to age 70 years) received after birth will also be calculated, together with the total effective dose (before and after birth) received by the offspring and its ratio to the total committed effective doses received by the mother. It is intended that dose coefficients will be given for all the elements and radionuclides in Publications 56, 67, 69 and 71. The results of some preliminary calculations are given in Tables $\mathrm{V}$ and VI.

TABLE V

Comparison of effective doses (Sv) to offspring and mothers for

$1 \mathrm{~Bq}$ acute intake by ingestion at start of week 10 of gestation

Comparaison des doses effectives (Sv) aux enfants et aux mères pour l'ingestion rapide de $1 \mathrm{~Bq}$ au début de la semaine 10 de gestation

\begin{tabular}{|c|c|c|c|c|c|}
\hline \multicolumn{6}{|c|}{ 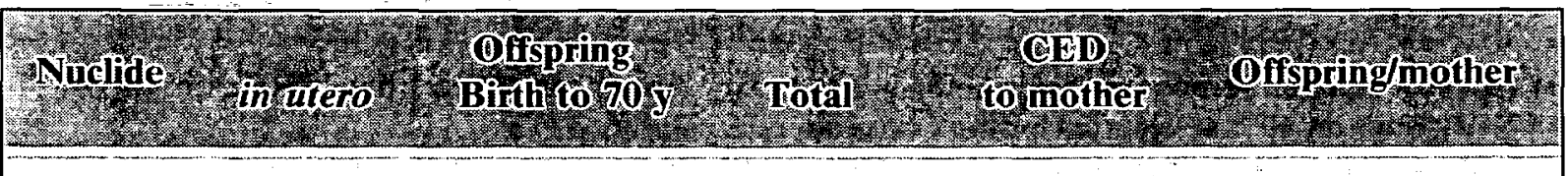 } \\
\hline HTO & $2.510^{-11}$ & $6.910^{-15}$ & $2.510^{-11}$ & $1.810^{-11}$ & 1.4 \\
\hline $106 \mathrm{Ru}$ & $2.810^{-10}$ & $2.510^{-11}$ & $3.010^{-10}$ & $1.010^{-8}$ & 0.03 \\
\hline${ }^{131} \mathrm{I}$ & $4.010^{-8}$ & $3.210^{-17}$ & $4.010^{-8}$ & $2.210^{-8}$ & 1.8 \\
\hline${ }^{137} \mathrm{Cs}$ & $1.010^{-8}$ & $5.010^{-10}$ & $1.110^{-8}$ & $1.310^{-8}$ & 0.80 \\
\hline${ }^{239} \mathrm{Pu}$ & $6.610^{-10}$ & $4.210^{-9}$ & $4.910^{-9}$ & $2.510^{-7}$ & 0.02 \\
\hline
\end{tabular}

In general, the results of the calculations indicate that for many radionuclides doses to the fetus will be less than those to the mother. For isotopes of caesium and for other radionuclides that equilibriate rapidly in the body, the dose to the newborn child is expected to be similar to that of the mother, although the total committed dose may be less. For intakes of ${ }^{131}$ I late in pregnancy, the dose to the newborn child may approach twice that of the mother. 
Similarly, intakes of alkaline earth radionuclides towards the end of pregnancy can result in higher doses to fetal tissues at birth than to maternal tissues, although the total committed dose to the offspring, at least for long-lived radionuclides, will be less than the mother. There is little suggestion that doses to the child will be appreciably higher than maternal doses, particularly for chronic intakes by the mother either before or during pregnancy. It is expected that the report will be ready for publication in about 18 month's time.

\section{TABLE VI}

Comparison of effective doses (Sv) to offspring and mothers to birth for $1 \mathrm{~Bq}$ acute intake by inhalationa) at various times before and after conception Comparaison des doses effectives (Sv) aux enfants et aux mères à la naissance, pour la prise rapide de $1 \mathrm{~Bq}$ par inhalation, à diverses dates avant et après la conception

\begin{tabular}{|c|c|}
\hline \multicolumn{2}{|c|}{ 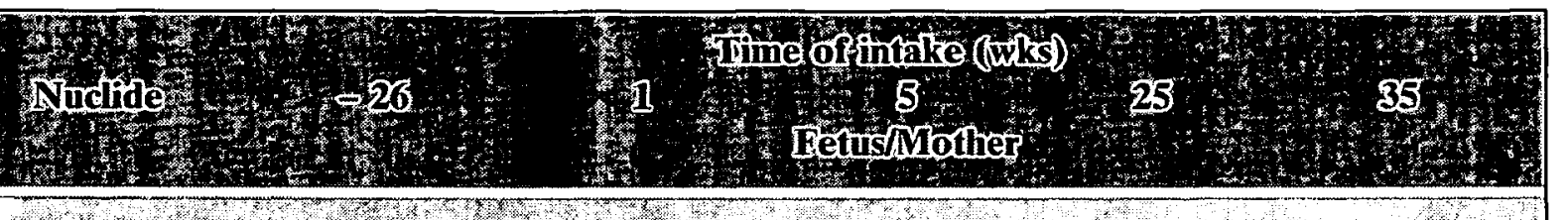 } \\
\hline 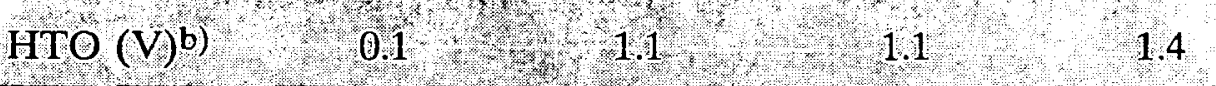 & 1.4 \\
\hline $\begin{array}{llll}106 \mathrm{Ru}(\mathrm{M}) & 0.01 & 0.03 & 0.02 \\
\end{array}$ & 1.01 \\
\hline 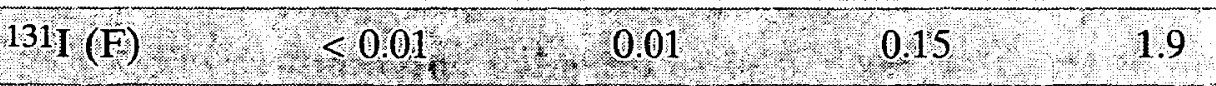 & \\
\hline 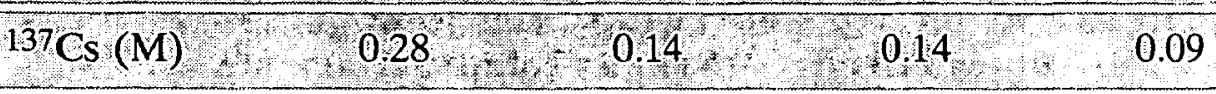 & ( \\
\hline $0.02=0.02$ & \\
\hline
\end{tabular}

a) Activity median aerodynamic diameter $=1 \mu \mathrm{m}$; b) Default lung type from ICRP publication 71 (17). $\mathrm{V}$ : vapour, $\mathrm{F}$ : fast clearance rate, $\mathrm{M}$ : moderate clearance rate.

\section{Reliability off dose coefficients}

The task group also has the responsibility for assessing the uncertainty and individual valiability associated with the point estimates of age-dependent dose coefficients given in publications 56, 67, 69 and 71. This aspect of the work of the group will address the reliability of the models for the respiratory tract and gastrointestinal tract used for assessing intakes of radionuclides as well as reviewing the merits of using the results of animal studies in conjunction with human data to develop age-dependent models for the tissue retention and excretion of radionuclides that have entered the blood. Additionally, the report will identify areas for future work. It will be prepared over the next 2 to 3 years. 


\section{REFERENCES}

International commission on radiological protection (ICRP) (1977) Recommendations (ICRP Publication 26). Pergamon Press, Oxford.

International commission on radiological protection (ICRP) (1979) Limits for Intakes of Radionuclides by Workers (ICRP Publication 30, Part 1). Pergamon Press, Oxford.

International commission on radiological protection (ICRP) (1980) Limits for Intakes of Radionuclides by Workers (ICRP Publication 30, Part 2). Pergamon Press, Oxford.

International commission on radiological protection (ICRP) (1981) Limits for Intakes of Radionuclides by Workers (ICRP Publication 30, Part 3). Pergamon Press, Oxford.

International commission on radiological protection (ICRP) (1989) Age Dependent Doses to Members of the Public from Intake of Radionuclides: Part 1 (ICRP Publication 56). Pergamon Press, Oxford.

International commission on radiological protection (ICRP) (1991) 1990 Recommendations (ICRP Publication 60). Pergamon Press, Oxford.

International commission on radiological protection (ICRP) (1993) Age Dependent Doses to Members of the Public from Intake of Radionuclides: Part 2, Ingestion Dose Coefficients (ICRP Publication 67). Elsevier Science Ltd, Oxford.

International commission on radiological protection (ICRP) (1994) Human Respiratory Tract Model for Radiological Protection (ICRP Publication 66). Elsevier Science Ltd, Oxford.

International commission on radiological protection (ICRP) (1995) Age Dependent Doses to Members of the Public from Intake of Radionuclides: Part 3, Ingestion Dose Coefficients (ICRP Publication 69). Elsevier Science Ltd, Oxford.

International commission on radiological protection (ICRP) (1995) Age Dependent Doses to Members of the Public from Intake of Radionuclides: Part 4, Inhalation Dose Coefficients (ICRP Publication 71).

Moore, K.L. (1977) The Developing Human. W.B. Saunders Co, London.

NEA/OECD (1988) Gastrointestinal Absorption of Selected Radionuclides: A report by an NEA expert group. Nuclear Energy Agency/OECD, Paris.

Smith, T., Veall, N. and Wootten, R. (1982) Bladder wall dose from administered radiopharmaceuticals: The effect on variation in urine flow rate, voiding interval and initial bladder content. Radiat. Prot. Dosim., 2, 183-189.

Snyder, W.S. and Ford, M.R. (1976) Estimation of doses to the urinary bladder and to the gonads. In: Radiopharmaceutical Dosimetry Symp., Proc. Conf. Oak Ridge, Tennessee, April 1976, HEW Publication (FDA 76-8044), pp. 313-349. Department of Health, Education and Welfare, Bureau of Radiological Health, Rockville, MD.

Stieve, F.E. (1984) Exchange and transfer of mechanisms of radioactive compounds between the mother and the developing off-spring in utero - review of the experimental literature. In: Effects of prenatal irradiation with special emphasis on late effects (C. Streffer and G. Patrick, Eds), pp. 159-185. EUR 8067 EU Commission of the European Communities.

Stieve, F.E. (1987) Placental transfer of other nuclides. In: Age-related factors in radioactive metabolism and dosimetry, pp. 315-325. Martinus Nijhoff, Dordrecht.

UNSCEAR (1977) Sources and effects of ionizing radiation: 1977 report to the General Assembly with Annexes. United Nations, New York. 